IUFRO division 8.02 - Mendel University Brno (Czech Republic) 2015

"Coppice forests: past, present and future"

Editors: Tomas Vrska, Renzo Motta, Alex Mosseler

\title{
Oak sprouts grow better than seedlings under drought stress
}

\author{
Justyna Pietras ${ }^{(1-2)}$, \\ Marko Stojanović ${ }^{(1-2)}$, \\ Robert Knott ${ }^{(2)}$, \\ Radek Pokorný ${ }^{(1-2)}$
}

\begin{abstract}
This study focused on the comparison of two contrasting forest regeneration types and their susceptibility to drought stress. Transpiration and biomass production were studied on young sessile oak trees Quercus petraea (Matt.) Liebl. regenerated as sprouts and seedlings, and grown in a coppice experimental site in the Czech Republic. Biomass production was estimated using destructive methods, while transpiration was derived from sap flow measurements and assessed according to the plant biometry and microclimatic conditions. Sprouts were characterized by a significantly higher diameter, height, leaf area and above-ground biomass and by a lower wood density as compared with seedlings of the same age. Moreover, the sap flow of sprouts was higher than that of seedlings, which was explained by the plant dimension. Transpiration, expressed as sap flow scaled to plant leaf area, did not differ between seedlings and sprouts when soil water was not limiting. However, during drought periods, when soil water potential dropped below -1.4 MPa, sprouts transpired significantly more than seedlings. Our results confirm that sprouts have access to a larger water pool via the old stump root system and are able to draw more water under drought. Moreover, sprouts seemed to be less susceptible to water limitations than seedlings of similar age. Less influence of drought on sprouts may partially explain their higher above-ground biomass production. Based on our results, coppice could be an appropriate management system to be adopted in sites characterized by frequent or extreme drought periods.
\end{abstract}

Keywords: Drought Stress, Sap Flow, Transpiration, Biomass Production, Sessile Oak, Coppice, Sprout, Seedling
2002) and as an alternative to urban forestry (Nielsen \& Moller 2008). Moreover, the coppice system has proved to be advantageous for slope stabilization, as fast-growing sprouts control soil erosion by intercepting precipitation and maintaining a vigorous, well-developed rooting network (Roy \& Morgan 2011).

Water availability is one of the most limiting factors for plant growth (Larcher 2003). Drought affects water relations and water use efficiency (Aroca 2012), alters
(1) Department of Biomass Production and Water Balance, Global Change Research Center, Academy of Sciences of the Czech Republic, v.v.i., Belidla 4a, 60300 Brno (Czech Republic); (2) Department of Silviculture, Faculty of Forestry and Wood Technology, Mendel University in Brno, Zemedelská 3, 61300 Brno (Czech Republic)

@ Justyna Pietras (pietras.j@czechglobe.cz)

Received: Aug 26, 2015 - Accepted: Jan 02, 2016

Citation: Pietras J, Stojanović M, Knott R, Pokorný R (2016). Oak sprouts grow better than seedlings under drought stress. iForest 9: 529-5357. - doi: 10.3832/ifor1823-009 [online 201603-17]

Communicated by: Tamir Klein the nutrient uptake and reduces photosynthesis (Farooq et al. 2009). Additionally, drought may lead to hydraulic failure and carbon starvation, due to decreased photosynthesis and transport of non-structural carbohydrates, and increase the susceptibility to other abiotic and biotic stress factors (Ryan 2011, McDowell 2011). Global climate change models predicted the occurrence of more frequent and severe drought periods in the future (IPCC 2007). The projected increase in temperature will cause greater evapotranspiration and surface drying. Along with unbalanced precipitation (long periods of dryness, extreme storms and increased run-off - Trenberth 2011), this may cause a severe water deficit during the growing season, especially in shallow soil layers, which are the most important for seedling establishment. Furthermore, drought reduces biomass production, decreases forest stability (Aranda et al. 2012), and increases tree mortality rates (Allen et al. 2010).

The regeneration type of stand recruitment (generative for seedlings or vegetative for sprouts) deeply affects the early development of new trees. Indeed, sprouts and seedlings show a different ability to 
use soil resources (nutrients, water) and compete with the surrounding vegetation. Several studies reported a faster initial growth of sprouts compared to seedlings, as they benefit from the existing root system of the stump (Dickmann et al. 1996, Bond \& Midgley 2001 Lloret et al. 2004, Vartiamäki 2009). Moreover, the rapid growth of sprouts can hamper the natural generative regeneration of stands, as sprouts can out-compete seedlings in the early stages (Vartiamäki 2009). The initial reduced ability of seedlings to uptake resources from the soil makes them more susceptible to water and nutrient stress (Savé et al. 1999). However, many physiological aspects of growth, biomass production and susceptibility to stress factors related to different regeneration forms have not been studied in detail.

We hypothesized that sprouts cope better with drought as they better tolerate water limitations compared to seedlings of similar age, resulting in a higher biomass production. The aim of the present study was to compare young sessile oak (Quercus petraea (Matt.) Liebl.) seedlings and sprouts in terms of biomass production, sap flow, transpiration, water use and susceptibility to water deficit in relation to plant biometry and microclimatic conditions.

\section{Material and methods}

\section{Site description}

The study was conducted at the experimental site of Mendel University in Brno, located near Sobešice, in the southeast of the Czech Republic ( $49^{\circ} 14^{\prime} \mathrm{N}, 16^{\circ} 35^{\prime} \mathrm{E}, 300$ $\mathrm{m}$ a.s.l.). The annual mean temperature of the site is approximately $7.5{ }^{\circ} \mathrm{C}$ and the average annual precipitation varies from 550 to $650 \mathrm{~mm}$ (Trouet \& Van Oldenborgh 2013). The main forest type of the experimental site (according to the Czech forest typology system) is rich oak-hornbeam with meadow-grass and soft-leaved sedge on a plateau and rounded ridges with some dry oak-hornbeam in exposed stands at lower altitudes (Kadavy et al. 2011). According to Plíva (1987), such forest types are significantly influenced by drought. The research site was established in the winter of 2009/2010 by cutting of a 73-year-old forest formed by $95 \%$ of sessile oak (Quercus petraea (Matt.) Liebl.) of predominantly coppice origin. The whole area (4 ha) was divided into 16 square-shaped plots of 2500 $\mathrm{m}^{2}$ differing in felling intensity (Kadavy et al. 2011). The study presented in this paper was conducted in one of the post-clearcut plots, with sessile oak regenerated naturally as seedlings and sprouts.

\section{Biometric characteristics}

A total of twenty-two plants (eleven sprouts and eleven seedlings) were harvested to compare their biometric characteristics. Before harvesting, plant height $(\mathrm{H}$, $\mathrm{cm}$ ) and stem diameter $10 \mathrm{~cm}$ above the stump/ground (i.e., base diameter $D_{0.1 m}$, $\mathrm{cm})$ were recorded. The cross-sectional area $\left(\mathrm{CSA}, \mathrm{cm}^{2}\right)$ was calculated on the basis of $D_{0.1 m}$. Leaf samples (ten per plant) were taken randomly from the upper part of the crown. Leaves were scanned fresh, then dried at $105^{\circ} \mathrm{C}$ to steady weight, and finally weighed. The specific leaf area (SLA, $\mathrm{cm}^{2}$ $\left.\mathrm{g}^{-1}\right)$ was calculated. Wood samples (ca. $5 \mathrm{~cm}$ long) from $10 \mathrm{~cm}$ above the ground/base were measured, dried at $105{ }^{\circ} \mathrm{C}$ to reach a constant dry weight and then weighed. Plant wood density $\left(\rho, \mathrm{g} \mathrm{cm}^{-3}\right)$ was calculated based on the wood sample volume and its dry weight. The age of plants was determined by counting the annual rings on cross-sections of the wood samples, taken at the same height. All plants were four years old. All the above-ground plant material was sub-divided into leaves, branches and stem, dried as described above and its dry biomass measured ( $\mathrm{g}$ plant ${ }^{-1}$ ). Specific leaf area and leaf biomass were used to calculate the entire plant leaf area (LA, $\mathrm{m}^{2}$ plant $\left.{ }^{-1}\right)$.

\section{Sap flow and transpiration}

Sap flow was measured based on the trunk heat balance method (THB - Lindroth et al. 1995, Cermak et al. 2004) and used to estimate the water consumption of seedlings and sprouts. The measurements were conducted from April to September 2014 on five seedlings and five sprouts in the same plot. EMS 62A sensors (EMS, Czech Republic) with external heating and internal temperature sensing were mounted on the plant stem below the foliage at a mean height of $25 \mathrm{~cm}$ above the ground/stump. The stem diameter at the position of sensors varied from 8 to $18 \mathrm{~mm}$. The measurement system was set to maintain a $4^{\circ} \mathrm{C}$ temperature difference between two thermocouples. The input power needed to maintain a fixed temperature difference was proportional to the amount of water passing the sensor (the sap flow Q, expressed in $\mathrm{kg} \mathrm{h}^{-1}$ ). Measurements were conducted every minute, while data averages were recorded at ten-minute intervals. Heat loss from sensors was eliminated from the total sap flow value on the basis of zero-flow baseline subtraction at 0300 $\mathrm{h}$, conducted using the Mini32 software pack (Mini32, EMS, Czech Republic). Sap flow measurements were used to calculate mean hourly and daily whole plant water fluxes. In order to compare plants of different sizes, sap flow data were scaled using the parameters $\mathrm{D}_{0.1 \mathrm{~m}}, \mathrm{CSA}, \mathrm{H}$ and LA. Plant leaf area was chosen as the best scaling parameter based on the coefficient of determination obtained from regression analysis. Sap flow scaled to plant LA was expressed as seedling and sprout transpiration $\left(E, \mathrm{~kg} \mathrm{~m}^{-2} \mathrm{~h}^{-1}\right)$ and used in further analyses.

\section{Microclimatic measurements}

The following microclimatic variables were recorded at the experimental site: global radiation ( $\mathrm{GR}, \mathrm{W} \mathrm{m}^{-2}$ ); air temperature $\left(\mathrm{T}_{\text {air }},{ }^{\circ} \mathrm{C}\right)$; relative air humidity $(\mathrm{RH}, \%-$ all the three variables measured by Minikin $\mathrm{RTHi}, \mathrm{EMS}, \mathrm{Brno}, \mathrm{CZ}$ ); precipitation ( $\mathrm{P}, \mathrm{mm}$ - MetOne 380, EMS, Brno, CZ); volumetric water content of soil (VWC, $\mathrm{m}^{3} \mathrm{~m}^{-3}-10 \mathrm{HS}$, Decagon Devices, Inc., Pullman, USA); and soil water potential (SWP, MPa - GB 2, EMS, Brno, CZ). Soil water potential and soil volumetric water content were measured using six sensors at the following three depths: 5, 30 and $55 \mathrm{~cm}$. All microclimatic variables were measured in one-hour intervals during the entire period of study. Microclimatic data were used to calculate the vapor pressure deficit (VPD, Pa) and the potential evapotranspiration $\left(\mathrm{ET}_{0}, \mathrm{~mm}\right)$ using the FAO modified Penman-Monteith equation (Allen et al. 1998), in order to detect periods of water stress.

\section{Drought stress indication}

The analysis of precipitation patterns, volumetric soil water content and soil water potential allowed to identify drought periods, defined as those days without precipitation, with a relatively high VPD and temperature (according to site-specific microclimate monitored for several years) and SWP below -1.2 MPa at the three measured soil depths. Drought stress was considered severe when SWP $<-1.5 \mathrm{MPa}$ and moderate when $-1.2<$ SWP $\leq-1.5 \mathrm{MPa}$ after Hsiao (1973). Climatic variables were used to distinguish periods with limiting and/or normal water conditions. Days under normal and dry soil conditions, but with comparable evaporative demand (GR, VPD, $\mathrm{ET}_{\mathrm{o}}$ ) were selected for the comparison of sprout and seedling transpiration.

According to Bequet et al. (2010), other indicators of water stress were recorded such as the continuously decreasing sap flow rate with no change in $\mathrm{ET}_{0}$, the decrease in the effective crown area $\left(A_{\text {eff }}, m^{2}\right)$ and the small relative effective crown area $\left(a_{\text {eff }}\right.$ \%). Plant sap flow and $\mathrm{ET}_{0}$ were quantitatively compared during days without precipitation, as suggested by Nicolás et al. (2005). The effective crown area of plants was calculated according to Bequet et al. (2010) as the ratio $\mathrm{Q} / \mathrm{ET}_{0}$, and the relative effective crown area as the ratio of the current-to-maximal effective crown area over the studied growing season (measured on $9^{\text {th }}$ and $10^{\text {th }}$ August). These parameters provide information on the extent to which the plant is able to follow the evaporative demands of the surrounding air. Low $A_{\text {eff }}$ and $a_{\text {eff }}$ indicate soil water stress conditions.

\section{Statistical analysis}

Statistical analyses were conducted using STATISTICA ${ }^{\circledast}$ version 12 (StatSoft Inc., Tulsa, OK, USA) and SigmaPlot ${ }^{\circledast}$ (Systat Software Inc., Chicago, IL, USA). Biometric data were analyzed by $t$-test, ANOVA and regression analyses. The $Q$ and $E$ of seedlings and sprouts were compared using the nonparametric Mann-Whitney U test. Simple 
and multiple regressions were used to analyze the relationships between transpiration, plant biometry, regeneration type and climatic conditions.

\section{Results}

\section{Biometric studies}

Most of the measured biometric parameters differed significantly between seedlings and sprouts (Fig. 1). Compared to sprouts, seedlings had a lower $\mathrm{H}$ and $\mathrm{D}_{0.1 \mathrm{~m}}$ by approx. $35 \%$ and $53 \%$, respectively. The differences in biomass of the various plant parts varied from $81 \%$ (leaves) to $87 \%$ (branches). It is worth noticing that the difference in the plant LA was approx. $77 \%$ greater for sprouts. Constrastingly, wood density was significantly higher in seedlings (approx. by $40 \%$ ), which was related to their slower stem diameter increment as compared with sprouts.

Sprouts and seedlings differed in the relations between the individual biometric parameters. The relation between $D_{0.1 m}$ [mm] and $\mathrm{H}[\mathrm{cm}]$ was strong for sprouts $\left(R^{2}=0.86, D_{0.1 m}=0.014 \times \mathrm{H}-0.538, \mathrm{p}<0.001\right)$ but not significant for seedlings. Plant leaf area was significantly related to $D_{0.1 m}$ in both plant types, with $\mathrm{R}^{2}$ being 0.75 and 0.84 for sprouts and seedlings, respectively. The linear regression function between plant leaf area $\left[\mathrm{m}^{2}\right]$ and stem diameter [mm] was $L A=0.84 \times D_{0.1 m}-0.39$ for sprouts and $L A=0.75 \times D_{0.1 m}-0.30$ for seedlings, respectively. $D_{0.1 m}$ was a suitable predictor of the total above-ground biomass [g], with the coefficient of determination $R^{2}=0.86$ for sprouts $(T A B=0.859 x$ $\left.D_{0.1 m}-0.538\right)$ and $R^{2}=0.93$ for seedlings $\left(T A B=0.927 \times D_{0.1 m}-255.99\right)$. The correlation between plant leaf area and plant height was not significant. The specific leaf area did not differ between seedlings and sprouts.

\section{Sap flow and transpiration}

During the entire measurement period, sprouts had a significantly higher sap flow (Q) compared to that of seedlings, with a mean daily Q $\left( \pm\right.$ SE) of $0.20 \pm 0.02 \mathrm{~kg} \mathrm{day}^{-1}$ for seedlings, and $0.50 \pm 0.04 \mathrm{~kg} \mathrm{day}^{-1}$ for sprouts. The higher $\mathrm{Q}$ of sprouts was monitored during entire study period, despite the soil water potential. The analysis of the relation between biometric data and $Q$ showed a high correlation of the latter parameter with the plant size. Regardless of plant type (vegetative or generative origin), the mean daily sap flow was best explained by the plant leaf area, then by CSA and $\mathrm{D}_{\text {o.1m. }}$. A low though significant relation was also found between $\mathrm{Q}$ and $\mathrm{H}$ ( Tab. 1).

As the mean daily sap flow was best explained by the plant $L A$, the observed $Q$ values were scaled to the LA and expressed as plant transpiration (E). Thus, the water consumption of different plant types was properly compared without the influence of the plant size. No significant diffe-

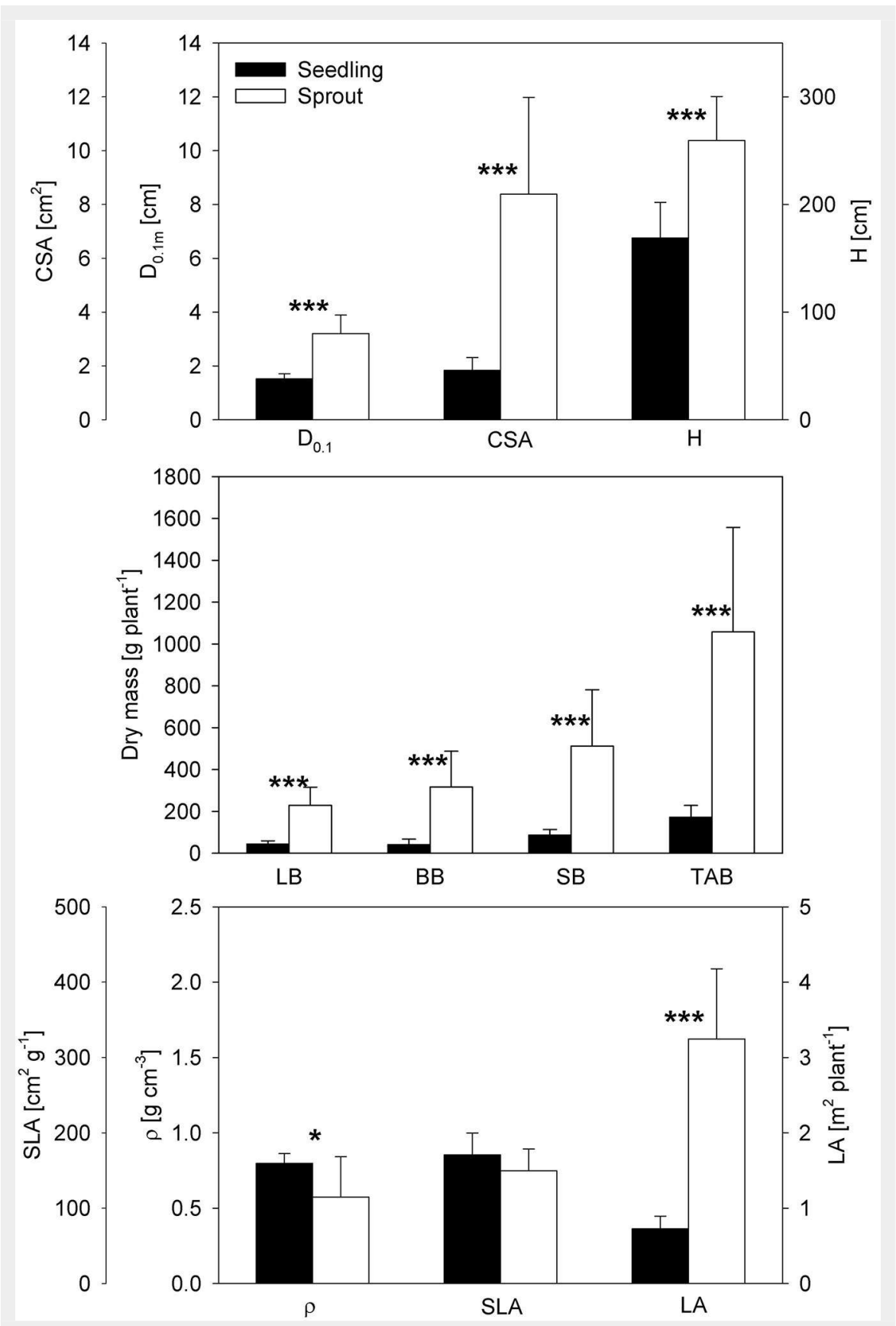

Fig. 1 - Comparison of seedling and sprout biometric characteristics. $\left(D_{0.1 m}\right)$ : plant stem diameter $10 \mathrm{~cm}$ above the ground/stump base (cm); (CSA): base cross-sectional area $\left(\mathrm{cm}^{2}\right)$; $(\mathrm{H})$ : height $(\mathrm{cm}) ;(\mathrm{LB})$ : leaf biomass (g plant $\left.{ }^{-1}\right) ;(\mathrm{BB})$ : branch biomass (g plant $\left.{ }^{-1}\right)$; (SB): stem biomass ( $g$ plant $\left.{ }^{-1}\right) ;(T A B)$ : total above-ground biomass ( $g$ plant $\left.{ }^{-1}\right) ;(\rho)$ : wood density $\left(\mathrm{g} \mathrm{cm}^{-3}\right)$; (SLA): specific leaf area $\left(\mathrm{cm}^{2} \mathrm{~g}^{-1}\right)$; (LA): leaf area $\left(\mathrm{m}^{2}\right.$ plant $\left.{ }^{-1}\right) ;\left({ }^{*}\right)$ : $\mathrm{p}<0.05 ;(* *): \mathrm{p}<0.01 ;(* *): \mathrm{p}<0.001$.

rences in the seasonal $E$ were found The variable $E$ was analyzed in several SWP between seedlings and sprouts. However, classes of 0.1 MPa. Differences in transpirathe relation between the transpiration of tion occurred when the soil water potential different plant types changed with SWP. dropped below -1.4 MPa, which is close to

Tab. 1 - Linear regressions of mean daily sap flow $(\mathrm{Q})$ as a function of plant height $(\mathrm{H})$, base diameter $\left(D_{0.1 m}\right)$, base cross-sectional area (CSA) and plant leaf area (LA).

\begin{tabular}{lccccc}
\hline Parameter & Intercept & b-value & $\mathbf{R}^{2}$ & adjusted $\mathbf{R}^{2}$ & $\mathbf{p}$ - value \\
\hline $\mathrm{H}$ & -0.547 & 0.007 & 0.67 & 0.39 & 0.0324 \\
$\mathrm{D}_{0.1 \mathrm{~m}}$ & -0.586 & 0.066 & 0.86 & 0.84 & 0.0001 \\
CSA & -0.133 & 0.296 & 0.92 & 0.85 & 0.0002 \\
LA & -0.019 & 0.262 & 0.94 & 0.93 & 0.0000 \\
\hline
\end{tabular}



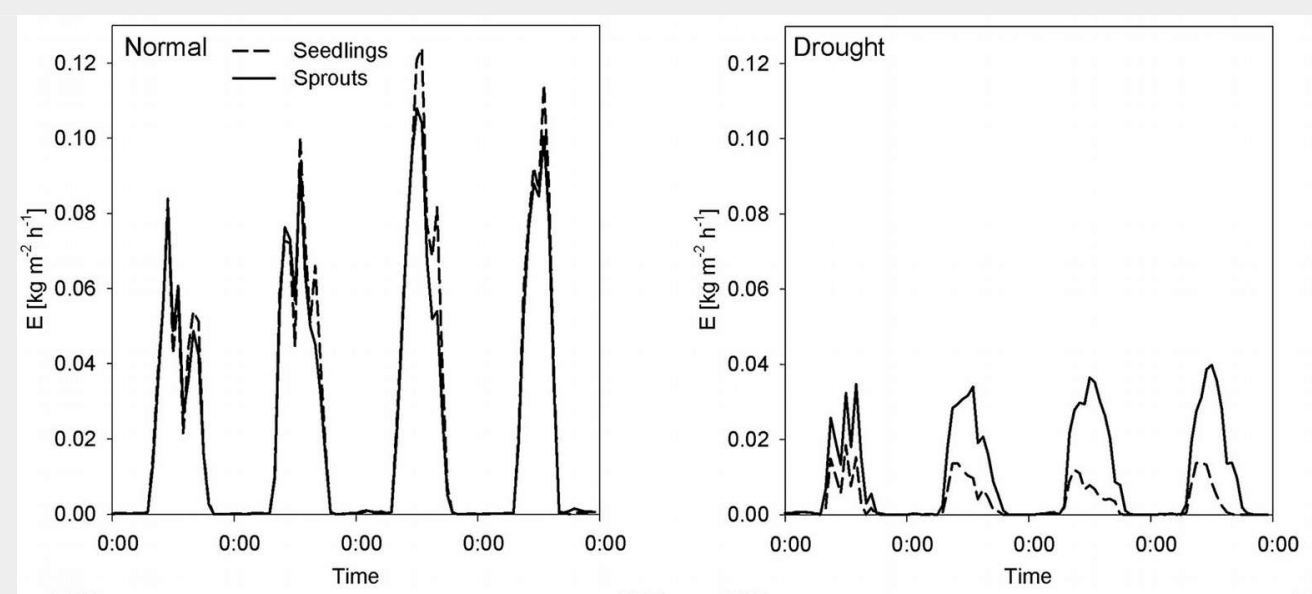

Fig. 2 - Seedling and sprout transpiration in relation to microclimatic variables in normal, non-limiting soil water conditions and in drought. (E): plant transpiration of seedlings (broken line) and sprouts (solid line); (VPD): vapor pressure deficit; (GR): global radiation.

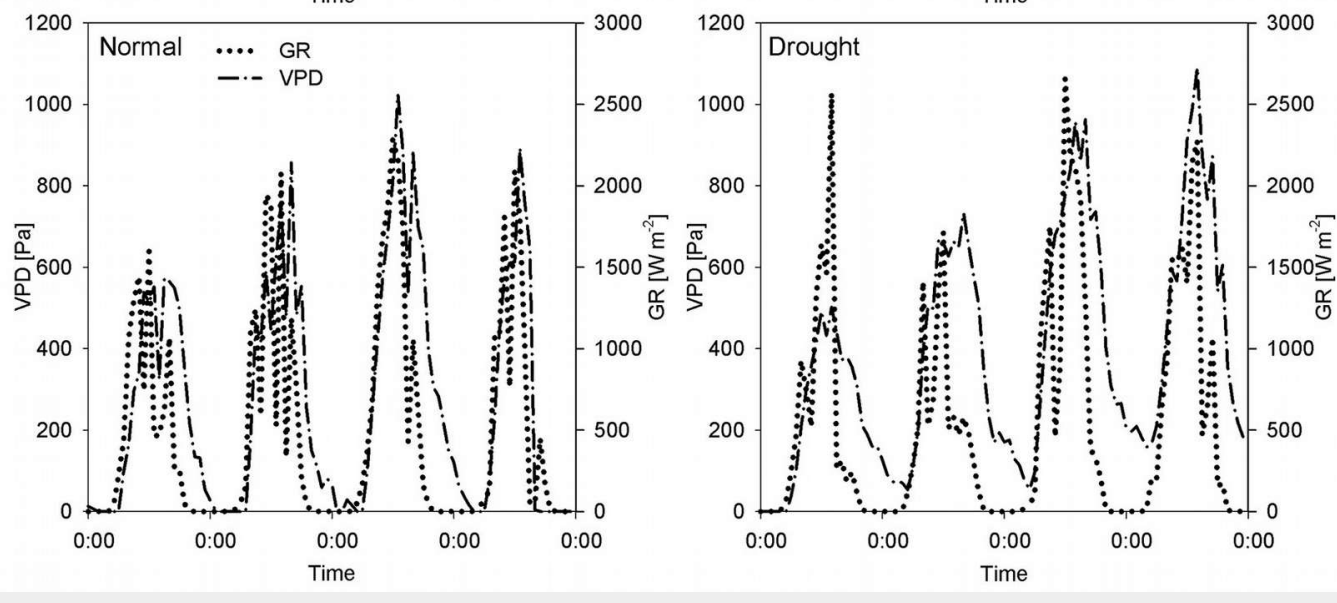

the severe water stress indicated by Hsiao (1973). Days with SWP <-1.4 MPa made up almost $40 \%$ of the studied period; therefore the difference in transpiration between sprouts and seedlings was meaningful in this growing season.

Two four-day periods with similar evaporative demand (i.e., $\mathrm{ET}_{0}$ values non-significantly different) but with contrasting soil water conditions, were chosen for a detailed comparison of seedling and sprout water relations (Fig. 2). The drought period selected for monitoring was $21^{\mathrm{st}}-24^{\text {th }}$ June while the non-limiting water conditions

period was $6^{\text {th }}-9^{\text {th }}$ August. Two-factorial ANOVA tests showed significant differences in daily transpiration between these two periods in seedlings and sprouts $(p=$ $0.00168)$. In the selected dry period, mean daily transpiration $( \pm \mathrm{SE}$ ) was $0.08 \pm 0.01 \mathrm{~kg}$ $\mathrm{m}^{-2}$ day $^{-1}$ for seedlings and $0.24 \pm 0.02 \mathrm{~kg} \mathrm{~m}^{-2}$ $\mathrm{day}^{-1}$ for sprouts. Under non-limiting water conditions, these values were $0.61 \pm 0.05$ $\mathrm{kg} \mathrm{m}^{-2}$ day $^{-1}$ and $0.56 \pm 0.03 \mathrm{~kg} \mathrm{~m}^{-2} \mathrm{day}^{-1}$ for seedlings and sprouts, respectively. Seedlings transpired under normal conditions eight times as much during drought, while sprouts approx. twice as much, which

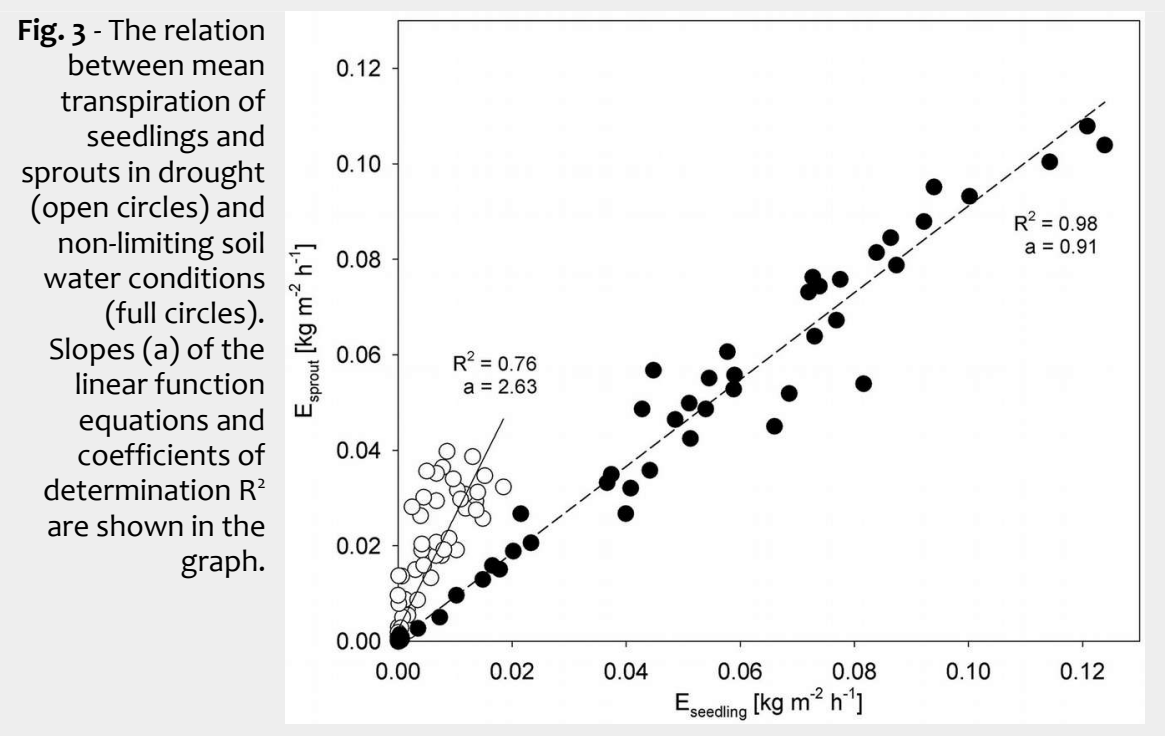

means a much greater decrease in transpiration of seedlings. Evidently, seedlings and sprouts differed in transpiration only during drought $(p<0.0001)$.

The diurnal curves of transpiration also changed during drought periods (Fig. 2). In non-limiting water conditions, transpiration showed a dome-shaped diurnal course, following changes in global radiation and the vapor pressure deficit. This pattern changed for seedlings during drought conditions, when sap flow decreased before midday despite of transpiration demands, and continued to fall in the afternoon. In non-limiting water conditions, seedling and sprout transpiration strongly correlated $\left(R^{2}\right.$ $=0.98$ - Fig. 3). This relation changed during drought stress, when $\mathrm{R}^{2}$ decreased and the slope of the regression function increased.

\section{Water stress indicators}

The effective crown area $\left(A_{\text {eff }}\right)$ was on average $( \pm \mathrm{SE}) 0.13 \pm 0.008 \mathrm{~m}^{2}$ for sprouts and $0.05 \pm 0.004 \mathrm{~m}^{2}$ for seedlings. The maximum (reference) $A_{\text {eff }}$ was $0.27 \mathrm{~m}^{2}$ for sprouts and $0.13 \mathrm{~m}^{2}$ for seedlings. The mean relative effective crown area $\left(\mathrm{a}_{\text {eff }}\right)$ was $39.7 \%$ for seedlings and $47.2 \%$ for sprouts. The $A_{\text {eff }}$ and $a_{\text {eff }}$ were much lower during the drought stress period, especially for seedlings. $A_{\text {eff }}$ was approx. one-third of these values lower in drought for sprouts, and almost one-tenth of these values for seedlings than during non-limiting water conditions (Tab. 2). The differences were 
not great during the non-limiting water conditions period.

\section{Discussion}

In our study, sprouts had a higher biomass and size compared to seedlings of the same age. Sprouts were characterized by a higher $H, D_{0.1 m}$, TAB and LA. Similar results have been previously reported by Dickmann et al. (1996), Lloret et al. (2004) and Vartiamäki (2009). Initial growth of sprouts is associated with some degree of mobilization of previously accumulated reserves of nutrients, starch, sugars and other soluble and insoluble energy reserves (Wildy \& Pate 2002). Sprouts benefit from the well-developed root system of a previously established tree (Bond \& Midgley 2001), thus more biomass can be allocated to above-ground structures. Moreover, compared to seedlings in the early development stage, water-use efficiency of sprouts can be greater due to the surplus of water and nutrients, thus their photosynthetic activity is not limited by resource availability (Drake et al. 2012). The slower above-ground growth rate of seedlings can be attributed to their higher investment of assimilates into the root system, in order to improve water and nutrient uptake.

The observed differences in growth rate and above-ground biomass production between the two studied plant types can also be related to the influence of the drought. Stomata are environmentally controlled gateways of plants, controlling $\mathrm{CO}_{2}$ uptake and transpiration, thus regulating photosynthesis, cooling and nutrient uptake (Farooq et al. 2009). Since transpiration and $\mathrm{CO}_{2}$ uptake occur in the leaf stomata, these two processes are strongly related (Cienciala \& Lindroth 1994). We found similar leaf-scale transpiration for seedlings and sprouts, suggesting similar photosynthetic rates during non-limiting water conditions. Contrastingly, seedlings had much lower transpiration during the drought period, as a consequence of the closure of stomata and soil water deficit. This response affects the net $\mathrm{CO}_{2}$ assimilation rate (Miyashita et al. 2005) and leads to lower plant biomass production (Brugnoli \& Bjorkman 1992, Mugnai et al. 2009). Additionally, drought often limits nutrient uptake (Aroca 2012), as water is required for their solubilization and translocation (Singh \& Singh 2004). Also, drought may lead to carbon starvation by interfering with the transportation of carbohydrates from the storage in the roots to aboveground tissue (Ryan 2011). Therefore, frequent and severe droughts dramatically affect biomass production. At drier sites, seedling growth may even be slower than that of sprouts due to a lower water uptake, as observed in this study and previously reported by Drake et al. (2012). As a result, in drought conditions sprouts have higher survival ability and faster growth than seedlings in the earliest ontogenetic stage (Lloret et al. 2004).

Tab. 2 - Mean effective crown area $\left(\mathrm{A}_{\mathrm{eff}}, \mathrm{m}^{2}\right)$ and relative effective crown area $\left(\mathrm{a}_{\mathrm{eff}}, \%\right)$ of seedlings and sprouts during non-limiting water conditions (Normal) and during drought. (DOY): day of the year.

\begin{tabular}{llccccc}
\hline \multirow{2}{*}{ Plant type } & Normal & \multicolumn{5}{c}{ Drought } \\
\cline { 2 - 7 } & DOY & $\mathrm{A}_{\text {eff }}$ & $\mathrm{a}_{\text {eff }}$ & DOY & $\mathrm{A}_{\text {eff }}$ & $\mathrm{a}_{\text {eff }}$ \\
\hline seedling & 218 & 0.112 & 84.9 & 141 & 0.017 & 12.8 \\
& 219 & 0.114 & 86.4 & 142 & 0.016 & 12.0 \\
& 220 & 0.112 & 84.5 & 143 & 0.008 & 6.4 \\
\multirow{3}{*}{ sprout } & 221 & 0.095 & 71.6 & 144 & 0.008 & 6.4 \\
& 218 & 0.265 & 97.4 & 141 & 0.087 & 31.9 \\
& 219 & 0.263 & 96.6 & 142 & 0.109 & 40.0 \\
& 220 & 0.237 & 87.0 & 143 & 0.075 & 27.5 \\
& 221 & 0.213 & 78.1 & 144 & 0.072 & 26.5 \\
\hline
\end{tabular}

Our results indicate lower water availability for seedlings during drought as a consequence of shallow roots and/or a smaller root absorptive area. Lloret et al. (2004) studied the response of Phillyrea latifolia seedlings and Quercus ilex sprouts to experimental drought. Generally, Quercus ilex is more susceptible to drought than $P$. latifolia in the adult stage of development. However, these authors reported a greater water use efficiency (WUE) and ability to regulate water use under stressful conditions for Q. ilex sprouts as compared with $P$. latifolia seedlings. This suggests that sprouts are less stressed by water limitation since they benefit from resources stored in parent trees. Therefore, the type of regeneration alters the competition among species in mixed forests, as regeneration by sprouting gives to susceptible species a better chance of survival to drought.

Drake et al. (2012) compared the transpiration and water use efficiency of young seedlings and sprouts of Eucalyptus globulus, finding a higher production of stem volume for sprouts compared to that of seedlings of 1-2 years. Transpiration was also higher in the case of sprouts both at individual and stand level. In their study, the difference in stand transpiration was mostly related to a significantly higher leaf area index (a greater surface area for transpiration) of the coppice. However, they did not find that the differences in transpiration were caused by a different level of stomatal control. In our case, differences in leaf area-scaled transpiration between seedlings and sprouts were observed under drought conditions, suggesting that plant origin can influence stomatal control when soil water is limited (i.e., SWP $<-1.4 \mathrm{MPa}$ ).

It has been reported that differences in transpiration rate between seedlings and sprouts are primarily related to the transmissive surface area (sap wood area or leaf area) for water transport (Drake et al. 2012). This implies that plants with similar basal and leaf area would transpire at similar rates regardless they are seedlings or sprouts. This is in contrast with our results, as the influence of drought on seedling and sprout transpiration was significant in this study.

Simultaneous measurements of sap flow and microclimatic factors allowed us to obtain valuable information on the water relations of trees and their response to changes in evaporative conditions and in physiological processes related to the water balance (Nadezhdina 1999), especially under limited soil water availability (Bequet et al. 2010). Such approach also enabled the analysis of several drought indicators. Our results showed a significant decrease in the effective crown area and in the relative effective crown area during drought for both seedlings and sprouts, which shows the limited ability of plants to meet the evaporative demands during drought stress. A low effective crown area suggests stressful conditions, water deficit and stomatal closure. In our study, the significant difference in $A_{\text {eff }}$ confirmed a more severe stress for seedlings, supporting the results of the transpiration analysis.

From the point of view of forest management, it is important to know how long the coppice system has an advantage over high forests in terms of production and water use, especially during droughts. Such advantage is connected to the differences in plant's biomass allocation and growth dynamics. Transpiration of coppice trees will likely be higher as long as its leaf area is higher than that of high forest trees. As plant leaf area can be explained by allometric relations to biomass and basal diameter of plants (as showed in this paper), the difference in transpiration would probably exist until seedlings (or young trees) reach a similar size to coppice trees. However, the absorptive root area and the root-toshoot ratio are the most important factors determining the water availability and transpiration of plants differing in their regeneration form (Savé et al. 1999). Therefore, seedlings may experience more severe water limitations than stump sprouts until they develop an extensive root system to withdraw water in drought periods. On the other hand, to our best knowledge, no studies comparing the root system of coppice and high forest trees and its development over time are available in the literature. However, in a study focused on the production at the stand scale, Giurgiu \& Draghiciu (2004) found that the total yield of a sessile oak coppice forest was equal to that of a high forest at the age of 40 years. 
Differences in water availability between coppice and high forest trees might theoretically exists at that age (or even later), though site-specific conditions should be taken into account.

Sessile oak is described as intermediately tolerant to drought (Arend et al. 2011, Dickson \& Tomlinson 1996). Several studies demonstrated that net assimilation of $\mathrm{CO}_{2}$, stomatal conductance and transpiration of sessile oak decrease to overcome drought, and remain substantially constant during severe stress (Bréda et al. 1993, Raftoyannis \& Radoglou 2002). In this study, the observed small (though still measurable) transpiration of seedlings and sprouts suggests an incomplete stomata closure under stress conditions. According to Thomas \& Gausling (2000), stomatal conductance strongly contributes to drought tolerance in oaks. Sessile oak is able to overcome a long-term water shortage (Bréda et al. 1993), although this may impair its biomass production and competition ability.

The increased initial biomass production and transpiration rate of sprouts under drought stress detected in this study suggest that coppice could be an appropriate management system in sites characterized by frequent droughts. In the context of the current climate change, a better understanding of drought response, survival, and mortality of trees (McDowell 2011), as well as the choice of the most appropriate management system, are critical to ensure long-term persistence of forests under the projected extreme drought.

\section{Conclusion}

Coppice and high forest differ in their regeneration form, and this affects the initial growth of trees, their utilization of resources and their susceptibility to stress factors such as drought. Significantly higher transpiration of seedlings during drought, together with the higher biomass production of sprouts under water shortage, confirmed the better performance of the coppice system as compared with high forest, at least during the initial stage of the forest development cycle.

\section{Acknowledgments}

This work was supported by the project "Coppice" no. CZ.1.07/2.3.00/20.0267. The authors thank the Internal Grant Agency of Mendel University in Brno for supporting this study with grant no. 36/2015. We would also like to thank Tereza Šlancarová and Pavlína Konrádová for their help with biomass analysis, Eva Darenová for her help with data processing, Jan Hobl for linguistic corrections and Matjaž Cater for his valuable comments and remarks.

\section{References}

Allen CD, Macalady AK, Chenchouni H, Bachelet $D$, McDowell $N$, Vennetier $M$, Kitzberger $T$, Rigling A, Breshears DD, Hogg EH, Gonzalez P, Fensham R, Zhang Z, Castro J, Demidova N, Lim JH, Allard G, Running SW, Semerci A, Cobb N
(2010). A global overview of drought and heatinduced tree mortality reveals emerging climate change risks for forests. Forest Ecology and Management 259: 660-684. - doi: 10.1016/j.for eco.2009.09.001

Allen RG, Pereira LS, Raes D, Smith M (1998). Crop evapotranspiration - Guidelines for computing crop water requirements. Irrigation and drainage paper 56, UN-FAO, Rome, Italy, pp. 333. [online] URL: http://appgeodb.nancy.inra. fr/biljou/pdf/Allen FAO1998.pdf

Aranda I, Forner A, Cuesta B, Valladares F (2012). Species-specific water use by forest tree species: From the tree to the stand. Agricultural Water Management 114: 67-77. - doi: 10.1016/j. agwat.2012.06.024

Arend M, Kuster T, Günthardt-Goerg MS, Dobbertin $M$ (2011). Provenance-specific growth responses to drought and air warming in three European oak species (Quercus robur, Q. petraea and Q. pubescens). Tree Physiology 31 (3): 287-297 - doi: 10.1093/treephys/tproo4

Aroca R (2012). Plant responses to drought stress: from morphological to molecular features. Springer, Heidelberg New York Dordrecht London, pp. 466. - doi: 10.1007/978-3-64 2-32653-0

Bequet R, Cermák J, Nadezhdina N, De Canniere C, Ceulemans R (2010). Tree water dynamics non-destructively assessed through sap flow measurements and potential evapotranspiration. Biologia Plantarum 54 (2): 366-368. - doi: 10.1007/s10535-010-0065-4

Bond WJ, Midgley JJ (2001). Ecology of sprouting in woody plants: the persistence niche. Trends in Ecology and Evolution 16 (1): 45-51. doi: 10.1016/S0169-5347(00)02033-4

Bréda N, Cochard H, Dreyer E, Granier A (1993). Field comparison of transpiration, stomatal conductance and vulnerability to cavitation of Quercus petraea and Quercus robur under water stress. Annals of Forest Science 50: 571-582. doi: 10.1051/forest:19930606

Brugnoli E, Bjorkman O (1992). Growth of cotton under continuous salinity stress: influence on allocation pattern, stomatal and non-stomatal components of photosynthesis and dissipation of excess light energy. Planta 187: 335-347. doi: $10.1007 / B F 00195657$

Cermak J, Kucera J, Nadezhdina N (2004). Sap flow measurements with some thermodynamic methods, flow integration within trees and scaling up from sample trees to entire forest stands. Trees 18: 529-546. - doi: 10.1007/s00468004-0339-6

Cienciala E, Lindroth A (1994). Gas exchange and sap flow measurements of willow trees in short-rotation forest. II. Diurnal and seasonal variations of stomatal response and water use efficiency. In: "Sap flow, transpiration and water use efficiency of spruce and willow in relation to climatic factors". Dissertation, Swedish University of Agricultural Sciences Department of Ecology and Environmental Research, Uppsala, Sweden, pp. 13.

Dickmann DI, Nguyen PV, Pregitzer KS (1996). Effects of irrigation and coppicing on aboveground growth, physiology and fine-root dynamics of two field-grown hybrid poplar clones. Forest Ecology and Management 8: 163-174. doi: 10.1016/0378-1127(95)03611-3
Dickson RE, Tomlinson PT (1996). Oak growth, development and carbon metabolism in response to water stress. Annals of Forest Science 53: 181-196. - doi: 10.1051/forest:19960202 Drake PL, Mendham DS, White DA, Ogden GN, Dell B (2012). Water use and water-use efficiency of coppice and seedling Eucalyptus globulus Labill.: a comparison of stand-scale water balance components. Plant and Soil 350 (1-2): 221235. - doi: 10.1007/s11104-011-0897-5

Farooq M, Wahid A, Kobayashi N, Fujita D, Basra SMA (2009). Plant drought stress: effects, mechanisms and management. Agronomy for Sustainable Development 29: 185-212. - doi: 10.1051/agro:2008021

Fujimori T (2001). Ecological and silvicultural strategies for sustainable forest management. Elsevier, Amsterdam, The Netherlands, pp. 412. [online] URL: http://books.google.com/books? id=mif6DLhlfwUC

Giurgiu V, Draghiciu D (2004). Modele matematico-auxologice si tabele de productie pentru arborete [Mathematic-auxologic models and yield tables for forest stands]. Ceres Publishing House, Bucharest, Romania, pp. 607.

Hsiao TC (1973). Plant responses to water stress. Annual Review of Plant Physiology and Plant Molecular Biology 24: 519-570. - doi: 10.1146/ annurev.pp.24.060173.002511

IPCC (2007). Climate change 2007: the physical science basis. Contribution of Working Group to the fourth Assessment Report of the Intergovernmental Panel on Climate Change (Solomon S, Qin D, Manning M, Chen Z, Marquis M, Averyt KB, Tignor M, Miller HL eds). Cambridge University Press, New York, USA, pp. 996.

Kadavy J, Kneifl R, Knott R (2011). Biodiversity and target management of endangered and protected species in coppices and coppiceswith-standards included in system of Natura 2000. Methodology of establishment of experimental research plots in the conversion to coppice and coppice-with-standards and their description. Mendel University, Brno, Czech Republic, pp. 57.

Larcher W (2003). Physiological plant ecology ( $4^{\text {th }}$ edn). Springer-Verlag, Berlin, Heidelberg, New York, pp. 517. [online] URL: http:// books.google.com/books?id=BgtzD4frr98C Lindroth A, Cermak J, Kucera J, Cienciala E, Eckersten $H$ (1995). Sap flow by the heat-balance method applied to small-size Salix trees in a short-rotation forest. Biomass and Bioenergy 8: 7-15. - doi: 10.1016/0961-9534(94)00085-8

Lloret F, Penuelas J, Ogaya R (2004). Establishment of co-existing Mediterranean tree species under a varying soil moisture regime. Journal of Vegetation Science 15 (2): 237-244. - doi: 10.1111/ j.1654-1103.2004.tb02258.x

Mason C, MacDonald SM (2002). Responses of ground flora to coppice management in English woodland - A study using permanent quadrants. Biodiversity and Conservation 11: 17731789. - doi: 10.1023/A:1020395014155

Matthews JD (1991). Silvicultural systems. Oxford University Press, Boston, MS, USA, pp. 296. [online] URL: http://books.google.com/ books?id=cRk6rgDJKbkC

McDowell NG (2011). Mechanisms linking drought, hydraulics, carbon metabolism, and 
vegetation mortality. Plant Physiology 155 (3): 1051-1059. - doi: 10.1104/pp.110.170704

Miyashita K, Tanakamaru S, Maitani T, Kimura K (2005). Recovery responses of photosynthesis, transpiration, and stomatal conductance in kidney bean following drought stress. Environmental and Experimental Botany 53 (2): 205214. - doi: 10.1016/j.envexpbot.2004.03.015

Mugnai S, Ferrante A, Petrognani L, Serra G, Vernieri $P$ (2009). Stress-induced variation in leaf gas exchange and chlorophyll a fluorescence in Callistemon plants. Research Journal of Biological Sciences 4: 913-921. [online] URL: http://www.medwelljournals.com/fulltext/? doi=rjbsci.2009.913.921

Nadezhdina N (1999). Sap flow index as an indicator of plant water status. Tree Physiology 19: 885-891. - doi: 10.1093/treephys/19.13.885

Nicolás E, Torrecillas A, Ortuño MF, Domingo R, Alarcón JJ (2005). Evaluation of transpiration in adult apricot trees from sap flow measurements. Agricultural Water Management 72: 131145. - doi: 10.1016/j.agwat.2004.09.008

Nielsen AB, Moller F (2008). Is coppice a potential for urban forestry? The social perspective. Urban Forestry and Urban Greening 7 (2): 129138. - doi: 10.1016/j.ufug.2008.02.005

Plíva K (1987). Typologický klasifikační systém ÚHÚL [Forest typology system of the Forest Management Institute of the Czech Republic]. Brandýs n.L., Czech Republic, pp. 55. [in Czech] [online] URL: http://www.uhul.cz/images/typo logie/Typologicky_klasifikacni_system_UHUL_P liva_1987.pdf

Raftoyannis Y, Radoglou K (2002). Physiological responses of beech and sessile oak in a natural mixed stand during a dry summer. Annals of Botany 89 (6): 723-730. - doi: 10.1093/aob/ mcf133

Roy PC, Morgan RJ (2011). Slope stabilization and erosion control: a bioengineering approach. Taylor and Francis Ltd., London, UK, pp. 274.

Ryan MG (2011). Tree responses to drought. Tree Physiology 31 (3): 237-239. - doi: 10.1093/tree phys/tpro22

Savé R, Castell C, Terradas J (1999). Gas exchange and water relations. In: "Ecology of Mediterranean evergreen oak forests" (Rodà $F$, Retana J Gracia CA, Bellot J eds). Series Ecological Studies, vol. 137, Springer-Verlag, Berlin, Germany, pp. 135-147. - doi: 10.1007/978-3-64258618-7_10

Singh B, Singh G (2004). Influence of soil water regime on nutrient mobility and uptake by Dalbergia sissoo seedlings. Journal of Tropical Ecology 45 (2): 337-340. [online] URL: http:// www.tropecol.com/pdf/open/PDF_45_2/45218. pdf

Thomas FM, Gausling T (2000). Morphological and physiological responses of oak seedlings (Quercus petraea and Q. robur) to moderate drought. Annals of Forest Science 57: 325-333. doi: 10.1051/forest:2000123

Trenberth KE (2011). Changes in precipitation with climate change. Climate Research 47: 123138. - doi: 10.3354/croog53

Trouet V, Van Oldenborgh GJ (2013). KNMI Climate Explorer: a web-based research tool for high-resolution paleoclimatology. Tree-Ring Research 69: 3-13. - doi: 10.3959/1536-1098-69.1.3 Van Calster H, Baeten L, Verheyen K, De Keersmaeker L, Dekeyser S, Rogister JE, Hermy M (2008). Diverging effect of overstorey conversion scenarios on the underground vegetation in a former coppice-with-standards forest. Forest Ecology and Management 256: 519-528. doi: 10.1016/j.foreco.2008.04.042

Vartiamäki H (2009). The efficacy and potential risks of controlling sprouting in Finnish birches (Betula spp.) with the fungal decomposer Chondrostereum purpureum. Dissertationes Forestales 93, Finnish Society of Forest Science, Natural Resources Institute Finland, University of Helsinki, University of Eastern Finland, Finland, pp. 31. [online] URL: http://www.metla. fi/dissertationes/df93.htm

Wildy DT, Pate JS (2002). Quantifying above- and below-ground growth responses of the western Australian oil mallee, Eucalyptus kochii subsp plenissima, to contrasting decapitation regimes. Annals of Botany 90: 185-197. - doi: 10.1093/aob/mcf166 